\title{
INTERVIEW
}

\section{OM POLITISKE UNDSKYLDNINGER}

\author{
Interview med David Scott
}

\section{ANNA KIRSTINE SCHIRRER}

Campus lå øde, da jeg dagen efter nytårsmorgen den 2. januar 2019 mødtes med professor David Scott på hans kontor i afdelingen for sociokulturel antropologi på Columbia University i New York City. I anledningen af min rolle som medredaktør af Tidsskriftet Antropologis temanummer Undskyld havde jeg bedt Scott, som også er min ph.d.-vejleder i antropologi på det samme universitet, om et interview til det forestående nummer vedrørende officielle politiske undskyldninger. Interviewet foregik på engelsk og er blevet oversat til dansk af temaredaktionen.

For nogle år tilbage sagde Scott under en samtale omkring erstatninger for historiske forbrydelser „,nobody cares about apologies anymore“ [ingen bekymrer sig om undskyldninger længere]. Jeg anede på én gang en særlig irritation hos ham over min forundring over fraværet af politiske undskyldninger i vores samtale om erstatningsret og samtidig en mere generel skuffelse over, at der i samfundsvidenskabelig forskning ikke er større interesse i undskyldningspolitik og officielle undskyldninger.

Scott har i en håndfuld år undervist et fag, han kalder Righting Wrongs. Slavery and Moral Repair, hvor officielle undskyldninger ikke fylder i pensum. Til sammenligning fokuserer jeg i min egen forskning fortrinsvis på erstatning frem for undskyldninger. Det var derfor med nogen forsigtighed, at jeg påbegyndte et interview om officielle politiske undskyldninger med Scott. Men i Danmark, navnligt i de danske medier, bekymrer vi os meget om undskyldninger for historiske forbrydelser, måske så meget, at vi har svært ved at skabe en samtale, der rækker ud over politiske undskyldningers retorik og symbolpolitik. Ligeledes er vores fokus i dette temanummer også på undskyldninger. Derfor var det på forhånd givet, at min samtale med Scott skulle omhandle undskyldningspolitik. Det særligt interessante ved min samtale med Scott denne anden nytårsdag var for mig, at Scott med sin karakteristiske sans for tidslighed flettede spørgsmålet om undskyldningspolitik og erstatning sammen, således at det ikke gav mening at disku- 
tere disse politiske, sociale, moralske og retlige fænomener separat fra hinanden. I Scotts karriere som politisk teoretiker og kulturel kritiker primært med fokus på det engelsktalende Caribien inklusive Jamaica, hvor han er født og opvokset i årene omkring landets uafhængighed, har emner såsom generationer, traumer, erindring, retsregimer og politiske bevægelser fyldt meget $i$ hans arbejde. Med sin dybe historiske bevidsthed i sin tilgang til antropologi er Scott en ekstraordinær samtalepartner i et personligt interview i dette nummer, der fokuserer på politiske undskyldninger i nyere antropologisk forskning i Danmark.

Hvordan har vores samtid ansporet dig til at skrive din kommende bog Irreparable Evil [red: ikke-genoprettelig ondskab], ${ }^{l}$ og hvorfor nu?

Der er ikke noget simpelt svar. I de seneste fire, måske seks år har jeg læst om og tænkt på erstatningsret og erstatning, særligt i relation til spørgsmålet om slaveri i den nye verden. Jeg har følt mig utilpas med den retning, som en stor del af forskningen i erstatningsret har taget. Jeg tror, at min utilfredshed har at gøre med det argument, der fremstiller forsoning som både nødvendigt og muligt. Flere ting er uklare for mig. For det første forekommer det mig, at kravet om forsoning er en ambition, en humanitær ambition, kunne man sige. Med andre ord: I et kosmopolitisk samfund - det vil sige i Jeremy Waldrons ${ }^{2}$ version af et kosmopolitisk samfund - skal vi være i stand til at „lade fortid være fortid“, at være enige om at se bort fra vores forskelle og om at være gode medborgere. Det slår mig, at dette argument er struktureret som et krav om, at de, der er blevet gjort til ofre, accepterer at sætte deres vrede til side og imødekommer - igen ved hjælp af Jeremy Waldron - det kantianske ${ }^{3}$ krav om et slags kosmopolitisk samfund. Det kommer ofte til at fremstå som et forslag, hvor de, der er blevet krænket eller gjort til ofre eller er efterkommere af dem, der er blevet krænket eller gjort til ofre for de systemiske grusomheder, som vi har kendt i den moderne verden, er opfordret til at imødekomme et krav, der stort set kommer fra de mennesker, der er blevet begunstiget af disse overtrædelser. Så dette argument har en paternalistisk grundstruktur, der bortset fra sin arrogance efter min mening indfører en ny form for epistemisk vold. Men der er også noget med, at argumenterne for forsoning ikke tager tilstrækkeligt hensyn til, at fortidens skader hverken er simple eller let overkommelige. Det er skader, der ikke er lette at komme igennem. Dit, Anna, nylige besøg i Sydafrika ${ }^{4}$ må have vist, hvor dybe disse sår er. For at svare mere direkte på dit spørgsmål: Jeg mener, at det er en slags progressiv optimisme, der former forsoningsargumentet og som begreb er uholdbart samt moralsk og politisk fattigt. Jeg overvejer i stigende grad, hvordan grusomheder producerer skader, som ikke kan repareres. Jeg siger ikke, at intet kan eller bør gøres: Et argument om forsoningsløshed er ikke et argument om, at erstatningskrav ikke skal 
fremsættes, at forpligtelser ikke skal overholdes. Men det er at begynde bagfra. Ikke med den antagelse, at skader gradvist kan repareres, men at begynde med spørgsmålet om, hvorvidt disse skader faktisk kan repareres, og hvis de ikke kan repareres, hvordan skal vi så tænke om nutiden i forhold til fortiden?

Du fokuserer her mere på forsoning end på erstatning, vil du fortcelle mere om det?

Ja, du har helt ret. Med forsoning mener jeg den bredere idé, at erstatning vil muliggøre forsoning. Jeg tvivler på, at vi kan antage den slags forhold mellem fortiden, nutiden og fremtiden, som underbygger den progressive idé, at slaveri kan blive gjort godt igen igennem erstatning, hvad enten erstatningen er materiel eller symbolsk.

Titlen på dette temanummer af Tidsskriftet Antropologi er Undskyld. Hvilke tanker har du om voerdien ved at studere genealogier af politiske undskyldninger, og hvad kan voerdien af sådanne undersøgelser vore?

Jeg tror, at der er mange fordele eller meget at opnå ved at undersøge spørgsmålet om politiske undskyldninger, både moralsk og retsligt. Moralsk til at begynde med: Det er umuligt at forestille sig erstatning for en overtrædelse, uden at der har været en anerkendelse af, at der er blevet begået en overtrædelse, og uden en anerkendelse af, at man i fremtiden vil afstå fra at begå denne slags overtrædelser. Der er efter min mening ikke nogen form for erstatninger, der kan finde sted uden en formel undskyldning. Hvilke former disse undskyldninger skal have, kan måske være forskellige. Men man kan ikke lægge ud med at fortryde sin formodning om og indbildning af overlegenhed - en formodning, som understøtter overtrædelsen til at starte med - uden en formel undskyldning, der genindfører betingelserne for intersubjektiv lighed. At gøre skade på et andet menneske og samtidig ikke at ville reparere denne skade viser, at den, der har gjort skaden, formoder, at han eller hun kan gøre skade på et andet menneske, og at det andet menneske tilhører en kategori af mennesker, som han eller hun kan gøre skade på. Dette er ikke mit, men blandt andre Bernard Boxills ${ }^{5}$ argument. Det er påstanden om en slags hierarki og derfor om en slags moralsk overlegenhed. Uden en undskyldning er der ingen formel måde at demonstrere for dem, som man har gjort til ofre for en overtrædelse, at du giver afkald på dette hierarki og på denne formodning om overlegenhed, og at den anden tilhører den klasse af personer, som man kan forvolde sig på. Så undskyldninger er moralsk afgørende for enhver form for erstatning. Men undskyldninger har også i stigende grad et juridisk fundament. Hvis jeg husker korrekt, er det skrevet i Romtraktaten, at en undskyldning for en overtrædelse er et juridisk instrument, som i sig selv har 
store implikationer, fordi det er en genkendelig juridisk form for anerkendelse af en overtrædelse. En overtrædelse må anerkendes både moralsk og retsligt i den verden af politiske stater, som vi bor $i$, for at en legitim retslig erstatning kan fremkomme. Så politiske undskyldninger er afgørende, både moralsk og retsligt. Det er klart, at staternes modvilje - både de europæiske stater og i USA - til at anerkende de overtrædelser, de historisk har begået, og den omhu, som enhver erklæring om fortrydelse demonstrerer, har delvis at gøre med bekymringen for de juridiske konsekvenser, som en officiel anerkendelse af - og undskyldning for - en historisk overtrædelse måtte have.

Hvilken slags undskyldning kan gives inden for en politisk, historisk, moralsk og juridisk kontekst af ugenoprettelig ondskab?

En fuldstændig, detaljeret og nøjagtig formuleret undskyldning for den bredere historie såvel som for de mere specifikke begivenheder, hvorigennem det koloniale projekt - i hvert fald i det tilfælde, der interesserer mig specifikt, slavehandlen og plantageslaveriet - blev iværksat. Man ønsker ikke en undskyldning, som blot er et statsritual. Alle offentlige undskyldninger, alle statslige undskyldninger vil være delvist performative. Det vil være den måde, hvorpå staten forsøger både at anerkende en overtrædelse og at frigive sig selv: Staten har som ønske at komme videre. Hvad man ønsker at gøre klart, er, og dette er en del af problemet med ugenoprettelighed for mig, at en undskyldning ikke i sig selv lukker bogen om fortiden. En undskyldning må i en eller anden forstand anerkende, at selv om den tilbydes oprigtigt af staten - og hvad det betyder, er i sig selv afgørende - selv om staten giver en undskyldning $i$ alvor, med tyngde og med alle passende symbolske og følelsesmæssige indvendinger over for dem, der er blevet uretfærdigt behandlet, lukker denne forestilling ikke i sig selv historien om fortiden. Der er skader, hvis sår ikke kan heles. En officiel undskyldning må erkende, at en undskyldning er en gestus, foruden hvilken en samtale om erstatning ikke er mulig, samtidig med at undskyldningens indledning ikke i sig selv garanterer, at fortiden, som den taler til, er en fortid, der nu bare ligger bag os.

Politiske undskyldninger bliver nødt til at være en del af en større bevægelse for erstatning. Ellers har de ingen nytte. En politisk undskyldning kan være en åbning fra staten for en anerkendelse af fortiden, for fortidens overtrædelser og en vilje til at være åben, retfærdig og til at være villig til at adressere de materielle konsekvenser af fortidens grusomheder. I dette tilfælde taler vi naturligvis om de økonomiske strukturer for grundlæggende ulighed såvel som racismens sociale struktur. Det er til dels det, der gør CARICOMs støtte til et erstatningskrav i Caribien interessant, fordi dette er stater, der kræver erstatning fra den tidligere aggressor, europæiske stater. Dette er stater, der taler på vegne af deres 
borgere og kræver erstatning. Det er ikke enkeltpersoner, der søger en international domstol. Dette er stater. Jeg synes, det er et meget tankevækkende eksempel. Hvorvidt man kan sige, at den britiske dronnings undskyldning til maorierne eller de amerikanske præsidenters undskyldning til japanskamerikanere eller til japanskcanadiere udgør vellykkede officielle undskyldninger, er svært at afgøre. En del af spørgsmålet om erstatning og erstatningskrav har at gøre med, hvordan de involverede befolkninger i dag fortsat lever under omstændigheder, der er direkte præget af fortidens grusomheder. Disse grusomheder har grundlæggende gjort disse befolkninger ude af stand til at transformere sig selv. Dette ligger til grund for det argument, som jeg gentager, og som ikke er introduceret af mig, at fraværet af erstatning for en historisk forbrydelse i sig selv er en overtrædelse. Der er altså den historiske forbrydelse, der blev begået, i dette tilfælde kolonisering og slaveri, men der er også det fortsatte og vedvarende fravær af erstatning for denne historiske forbrydelse, som er en overtrædelse. Hvilket vil sige at tilføje fornærmelse til skade, at forevige overtrædelsen. Det er at fortælle mennesker, at de er uværdige.

I hjertet af den del af min forskningsinteresse, der har at gøre med spørgsmålet om ugenoprettelighed, er det faktum, at kolonisering og slaveri ikke var en begivenhed, men en struktur. Det varede ikke en håndfuld år, et årti eller to, men generationer. Det var en struktur, der ikke var knyttet til en allerede eksisterende normativ ramme, kapitalisme, som vi kalder det. Det var en struktur, som var en integreret del af selve tilblivelsen af kapitalisme. De grundlæggende asymmetrier, der er produceret mellem Europa og dets Andre som en konsekvens af kolonisering og slaveri, er i sig selv ugenoprettelige. De er altså af en rangorden, der påkræver sig en form for erstatning, der grundlæggende vil ændre europæernes levevilkår. Jeg har det svært med det argument, som Janna Thompson, som jeg respekterer enormt, bruger om, at erstatningskrav skal imødekommes, alt andet lige. Hvem afgør, om alle ting forbliver lige? Erstatning fordrer, at intet kan forblive lige: at de, der er blevet begunstiget af kolonialt slaveri - det vil sige Europa - og ikke kun europæiske borgere, men selve strukturerne i det europæiske liv, et liv, der synes at være blevet bevaret fjernt fra de elendige former for socialt og økonomisk liv, der leves i den tidligere koloniserede verden - samt de livsbetingelser og den livskvalitet, som denne begunstigelse har gjort mulig, grundlæggende skulle ændres for at afhjælpe den ubalance, som kolonisering og slaveri indledte. ${ }^{6}$ Det forekommer mig at være noget, der skal konfronteres. Erstatning for det transatlantiske slaveri handler ikke om at returnere smykker, malerier eller en banktransaktion. Slavehandlen har muliggjort en del af oprettelsen af de store byer i Europa og i Nordamerika. Du kan ikke gå i en by i Europa uden at se, at arten af den rigdom, som du ser omkring dig, grundlæggende blev skabt på ryggen 
af slaver. Det minder mig om den bemærkning fra C.L.R. James, der åbner The Black Jacobins, hvor han skriver, at Frankrigs store rigdom blev bygget på ryggen af en halv million slaver. Derfor - hvad erstatninger kræver, er en karakter af en slags strukturel klage, der kræver ikke blot en retslig, men også en politisk bevægelse for at muliggøre.

Når samfundsvidenskabelige forskere i Danmark ønsker at skrive om erstatning, som for eksempel i året 2017, der markerede hundredåret for salget af de tidligere danskvestindiske øer, i dag De Amerikanske Jomfruøer, bliver en diskussion om erstatning ofte behandlet i medierne som en diskussion om en undskyldning. Man kan sige, at der er en overfokusering på officielle undskyldninger. Titlen på dette temanummer af Tidsskriftet Antropologi er desuden Undskyld, ikke „Erstatning “. Hvilke slags samtaler tror $d u$, at et fokus på erstatning muliggør, som et fokus på officielle undskyldninger kan stå $i$ vejen for?

Jeg tror, at disse spørgsmål er integrerede i hinanden. En undskyldning er en form for anerkendelse af ansvarsfordelingen. Det er en ansvarsfordeling, som gerningsmændene påtager sig, men endnu vigtigere en ansvarsfordeling, som de, der er blevet begunstiget af uretmæssige spil og af at tage andre territorier i deres besiddelse og drage fordel deraf, påtager sig. Så anerkendelse og ansvarsfordeling er vigtigt for mig og særligt, fordi det hænger sammen med andre ting. Disse andre ting er grundlæggende et spørgsmål om at afhjælpe de materielle ubalancer mellem det, der eufemistisk kaldes det globale nord og det globale syd, men som er de tidligere kolonimagter og de tidligere koloniserede stater. De tidligere danskvestindiske øer er praktisk talt stadig en koloni. Hvad det betyder materielt, mener jeg er et grundlæggende spørgsmål. Europa blev skabt af kolonisering. Europa opstod ikke af sig selv. Det moderne Europa, som er det, Europa er, og skabelsen af Europa blev på bekostning af andre verdener. Skabelsen af Europa var afhængig af ødelæggelsen og genskabelsen af de verdener, de dominerede, som en moderne periferi. Det er ikke blot et spørgsmål om at tilbyde en undskyldning. Det, der er afgørende, er, at stater sætter sig ned og taler om den rigdom, de udvandt af det arbejde, der blev foretaget på ryggen af de koloniserede. En del af problemet med CARICOMs erstatningskrav i Caribien er, at de er del af en større nyliberal orden. Spørgsmålet om, hvordan vi kan gentænke fremtiden, eller hvad social lighed betyder, eller hvad politisk deltagelse betyder, for eksempel at ville vende tilbage til vigtige spørgsmål om socialisme, til en transformeret politisk orden, er ikke på dagsordenen. Erstatning kan efter min mening ikke betyde noget, hvis det udelukkende indebærer en overdragelse af ressourcer til neoliberaliserede stater og deres korrupte politikere. Spørgsmålet om erstatning skal være en del af en større diskussion om social og politisk transformation. 
Hvad håber du at videregive med din kommende bog Irreparable Evil til fremtidige forskere i erstatningsret?

Jeg er en stor tvivler. En stor del af mit arbejde igennem en årrække har været at forsøge at bremse det, der forekommer mig at være en uholdbar form for progressivisme. Det vil sige en uholdbar antagelse om, at vi ved, hvor vi skal hen, at alt, hvad vi har brug for, er at samle vores ressourcer og mobilisere befolkningen mod en fremtid, der ligger foran os. Jeg tror, at denne antagelse er resterne af de store progressive doktriner fra det 20. århundrede, både liberalisme og marxisme. Vi må på grundlæggende måder gentænke, hvordan man forbinder en historie om fortiden med en historie om, hvad der er galt med nutiden, for at kunne forbinde disse to [red: tider] med nye spørgsmål om, hvad vi ønsker af den fremtid, der måtte ligge foran os. I forholdet mellem fortid, nutid og muligvis fremtid mener jeg, der findes mange ringe konceptuelle tanker. Af forståelige politiske grunde. Det forekommer mig, at vi er nødt til i højere grad, end vi hidtil har gjort det, at konfrontere, hvordan vi synes, at disse forbindelser bør tænkes. Det indebærer blandt andet - og her er mit arbejde med tragedien ${ }^{7}$ naturligvis en del af det - at tænke igen og igen på, hvordan menneskelig handling er uforudsigelig, og på, hvordan menneskelig handling kan fortrydes. Men nogle menneskelige handlinger sætter kursen for en bevægelse, som man ikke bare lige kan stoppe; man kan ikke særlig nemt hele sår, når først de er åbnet. Jeg bliver ved med at citere George Steiner, som sagde: „Ødipus fik aldrig sine øjne tilbage.“ Der er ikke noget, der kan give Ødipus sine øjne tilbage. Der er visse skader, der ikke kan repareres. I et forsøg på at genoverveje spørgsmålet om fortiden og dens forhold til nutiden må vi være i stand til at spørge os selv om, hvordan vi bærer byrderne af vores egne fiaskoer, af ældre generationers fejl og af yngre generationers mulige fejl. Denne fiasko skal tænkes mere integreret ind i den politik, vi ønsker at vedtage. Ugenoprettelighed synes at være afgørende i de tanker, såvel som spørgsmålet om det onde er det. Disse to er for mig forbundet. Der findes fortider, som ikke længere blot kan installeres i en progressivistisk rytme, hvor man forestiller sig, at de overtrædelser, der blev begået i fortiden, kan transcenderes i en fremtid, hvor tidligere former for overtrædelser eller undertrykkelse eller dominans, eller hvad end vi skal kalde det, ikke findes. Der er nogle typer overtrædelser af en særlig orden, som for mig synes at være uigennemtrængelige, upåviselige, utrolige. De er af en rangorden, som stiller dem uden for en rationel diskurs.

Hvilke forskningsområder i fremtidige studier af statsansvar for historiske uretfardigheder betragter du som scerligt vigtige? Hvilke koncepter eller metoder $i$ studiet af politiske undskyldninger, erstatning og koloniale forbrydelser tilskriver du central betydning? 
Jeg besvarer aldrig den slags spørgsmål, primært fordi jeg ikke ved hvordan. I forhold til mit eget arbejde følger jeg min næse, uanset hvor den dirigerer mig hen. Jeg synes, den forskning, du laver, er vigtig, forskning, der ser på lovbestemte organisationer og statsstrukturer i nationalstater, der fremsætter krav, fordi jeg synes, det er vigtigt at forstå forholdet mellem politikken i nationalstater, ligesom nationalstater i det engelsktalende Caribien, og det øjeblik, erstatningskrav fremstår som den retning, man som stat skal tage. Under den antikoloniale periode og de to første årtier efter uafhængigheden i det engelsktalende Caribien var erstatningskrav af denne art ikke på dagsordenen. Erstatningskrav er nu blevet det sprog, hvorigennem disse postkoloniale stater forsøger at tackle fortidens arv i nutiden. Som jeg har skrevet det i min korte henvisning til Hilary Beckles' bog, ${ }^{8}$ tror jeg, det er et interessant skridt for de postkoloniale stater at hævde, at erstatning udgør en ny fase af et udviklingsprojekt. Jeg synes, det er værd at undersøge mobiliseringen af dette erstatningskrav og dets politiske retorik, og hvilken virkning det vil have, hvis det har tilstrækkelig politisk støtte, både nationalt, regionalt og internationalt. Og jeg tror, det er værd at udforske, hvordan man forstår disse forhold over for disse nationalstaters politik og politiske økonomier. Hvordan er det, at retorikken om social transformation i form af et radikalt socialt demokrati eller socialisme af en eller anden slags - bevægelser sammenlignelige med 1960'ernes og 1970'ernes politiske bevægelser - er forsvundet hos disse nationalstater? At disse stater er strukturelt tilpassede, og erstatning nu er blevet det formsprog, hvorigennem udvikling formuleres?

I dag er det ikke et spørgsmål om at være imod en politiske retning. Men hvordan skal vi forstå, hvad der politisk foregår i disse postkoloniale stater, hvor erstatningskrav tilsyneladende skal betragtes som en artikulering af udvikling? Hvorfor var erstatningskrav fraværende i tidligere øjeblikke? I Les Dámnes de la Tierre fremkalder Franz Fanon erstatningskrav i et kort øjeblik. Han formulerer aldrig et systematisk argument om det, men det er bestemt at finde i The Wretched of the Earth. Det var aldrig et afgørende udtryk for en antikolonial eller postkolonial politik. Først to-tre årtier efter uafhængighed er det opstået som sådan. Det, synes jeg, er afgørende, og jeg synes, det er enormt vigtigt at prøve at forstå, hvad det drejer sig om i nutiden, hvad har ført til det, og hvordan indrammer denne konjunktur en særlig måde at formulere spørgsmålet om erstatning på? Jeg vil ikke lyde fortættet eller alt for kompliceret - det er simpelthen bare spørgsmålet om forholdet mellem erstatningskrav og liberalisme. Hvilket ikke betyder, at det ene skal afskediges til fordel for det andet, men at man skal prøve at tænke dette forhold mellem erstatningskrav og liberalisme igennem og tænke igennem, hvad der er muligt, og hvad der ikke er muligt i forhold til liberal og nyliberal tænkning. 


\section{Noter}

1. Scotts bog Irreparable Evil udkommer på Duke University Press (ingen dato).

2. Den liberale retsfilosof Jeremy Waldron har skrevet bredt om erstatningsret og er især blevet kendt for sin argumentation for ,at lade fortid være fortid“ eller „to let bygones be bygones“ (Waldron 1992).

3. Scott refererer her til en repræsentation af Emmanuel Kants ,,proximity principle“ (i Waldron 2002:135-60). Waldron citerer Kant og skriver: ,each person has the right to approach other peoples in the world with a view of 'offering to engage in commerce"“ (ibid.). Waldron, som selv er efterkommer af hvide britiske handelsrejsende og bosættere i New Zealand, refererer her til, at europæiske bosættere under koloniseringen var berettiget til at nærme sig andre mennesker og tilbyde at indgå $i$ handel med dem. Hverken Kant og Waldron forholder sig til de voldelige overgreb, der muliggjorde bosættelse og et handelsvirke, er den underliggende liberale kosmopolitiske idé, at multikulturelle bosætterstater såsom Australien, New Zealand, på det afrikanske kontinent og på det nord- og sydamerikanske kontinent har en forpligtigelse til at lade en voldelig fortid være fortid og fokusere på en fælles harmonisk fremtid.

4. David Scott refererer til interviewer Anna Kirstine Schirrers deltagelse i konferencen Recognition, Reparation, Reconciliation, Stellenbosch University, Cape Town, Sydafrika, december 2018.

5. Scott refererer her til filosoffen og socialteoretikeren Bernard Boxills essays „The Morality of Reparations“ (Boxill 1972) og „The Morality of Reparations II“ (Boxill 2003).

6. På originalsproget lyder sætningen: „Because reparatory justice will require that all things can't remain equal; that the beneficiaries of colonial slavery, meaning Europe - and not just meaning European citizens, but the very structures of European life that seemed to be preserved away from the abysmal forms of social and economic life lived in the colonial world, colonised places, that those conditions of life, that quality of life would have to be altered fundamentally, in order to redress the imbalance that colonial slavery initiated."

7. Se blandt andet Scotts tredje bogudgivelse Conscripts of Modernity. The Tragedy of Colonial Enlightenment (2004).

8. Scott refererer her til Hilary Beckles' bog Britain's Black Debt. Reparations for Caribbean Slavery and Native Genocide (Beckles 2013).

\section{Litteratur}

Beckles, Hilary

2013 Britain's Black Debt. Reparations for Caribbean Slavery and Native Genocide.

University of West Indies Press.

Boxill, Bernard

1972 The Morality of Reparations. Social Theory and Practice 2(1):113-23.

2003 The Morality of Reparations II. In: Lott \& Pittman (eds): A Companion to African American Philosophy.

Scott, David

2004 Conscripts of Modernity. The Tragedy of Colonial Enlightenment. Duke University Press.

Waldron, Jeremy

1992 Superseding Historic Injustice. Ethics 103(1):4-28.

2002 Redressing Historic Injustice. The University of Toronto Law Journal 52(1):135-60. 
